\title{
East Asia in the Twenty-First Century: Economic Cooperation and Political Rivalry
}

\author{
SHINICHI ICHIMURA \\ Intermational Centre For the Sudy of Lasis Asian Development
}

The article focuses on trade, investment, financial transactions, migration and other economic and political relations between China and other East Asian countries, which are reilassiffed as continental and. insular Asia. Although there is great political and economic uncertain. ty in East Asia toward the end of this century and in the next milleniun, a feu trendi are observable: 1) slower growth and the rise of domestic dissatisfaction, 2) unequal income distribution and regional disfarity, 3) liberal trade and investments, 4) competitive cooperation in Fist Asia without regional integration, 5) urban growth centers and sab regional development, and 6) the raed for regional balance in foreign direct investment. The balanse of pouse betueen insular Asia and continental Asia, particularly Chint, may be maintained via good understanding among Asian nations about the relations among economic development, political stability and security. Finally Japan's efforts for security and regional political stability can be achieved through maintaining trast in bilateral alliance with the United States, Rusita, China, und wher Asian conntrios, improning mutual trust smong insular Astion nations by confidence-bullding steps, specially with China and Korea, and achieving arms control or arms reduction by mutual dialogue to reduce tensions in East Asta.

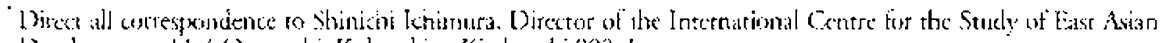

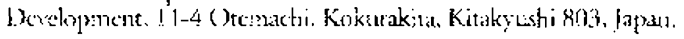


$I^{\prime}$ $t$ is bold to talk about what would happon to East Asia in the 2 lst century. It is obvious if one thinks whether onc could have predicted what would happen in the 20th century at the cnd of the 19 th century. But one could not say that there is no example in the history of political prognosis or scientific fiction that has predicted surpringlyly well the future problems facing some country's political situtation many decades ahead and proposed even policy suggestions for the country. One such example is the well-known 'Iani Kanjo Ikensho (Opinions of Kanjo Tani) presented to the Meiji government in the 22nd year of the Meiji era as early as 1887 . It is better known abroad as was translated and quoted hy E. Herbert Noman in his Japan's Emergence As A Modon State-Political and Economic Problems of the Meiji Period (1940). He wrote:

\footnotetext{
"What kinds of strategic policies should japan adopt then? I maintain: abolish all the traditional routine policies and ideologies, abandon the mind of dependence on others, reinforce the armaments, deepen the ditches and build up the fontess, keep international faith with foreign nations, ry to maintain the dignity and honor of the State, never do anything to bring disgrace to rhe country, uplift the spirits in crisis to defend the counery with the people, and simply sait for the rebellions in Furope. Europe will sooner or later face the situations which cause war and force many conntries to compete for supremacy in the workt. Our nation certainly should nor intervene in such struggles. Nevertheless, the impact of the wars in Europe will be so deep and wide that Fastern countries will also be affected and will inevitably be involved in the wars. Thesh our sation should not have any inceress in our relative importance to European narions but may be destined to assume the kadership among the Eastern countrics. If we have 20 strong laatleshijps and an elite troop of 200 thousand, then we can measure our strength in the halance of the Fastern countries and demonsmrate our weight to European powers."
}

The political and economic uncertainty of East Asia toward the end of this century and ahead of the next millenium goes without saying. Some trends in the politics and economics of East Asia in the next century, however, scem to be observable even to simpleminded social scientists. Indeed, some have alrcady artempted to give their own prognosis. Unfortunately, this author does not agree with some of those influential opinions. Let me use this opportunity to criticize their views and express some of my own humble opinions.

\section{THE TWEN'IEI'H CENTURY IN RETROSPECT}

It is sometimes said that the beginning half of the 20 th century is the period of politics and the last half is the period of economics. In East Asia there were a scries of international or civil wars in almost every decade since the last part of the 19th century: the Sino-Japanese War in 1894-95, the Russo-Japanese War in 1904-05, World War I in 1915-16, the Sino-Japanese Incident around Shanghai in 1930-31, the Sino-Japanese War from 1937 to the end of 1945, and World War II in Europe from 1938 to 1945 and in the Pacific from 19/1 to 1945. Common views may be that there have been no major 
wars since then, except for the cold war between the free world led by the United States and the Communist world led by the Soviet Union.

I lowever, even after 1945 therc have been major wars in. East Asia as well as the rest of the wotd: c.g., the Korean War and the Vietsam War. Thete wete also a number of civil wars or domesric power-struggles of which the sacrifices were not less serious than any other major wars in hisrory. The Great l.eap Forward Movement and the Culrural Revolution in Chind, ace believed to have caused the loss of atout 20 million human lives. The civil war in Cambodia sacrificed a fow million lives; the civil rioting and fighes in Malaysia more than tens of thousands; the one in Indonesia in 1965 more than half a million; and thosc in Burma also more than tens of thousands. Thes, to regard the latter balt of the 20 h century as just 50 vears of ecommic development, and more specifically as an age of a miraculous growth is a view that can hardly be justified. Nevertheless, one must adnit, the coonomic devetopment of Ease Asia has been most impressive in the last half of this century.

The dividing line between the heginning and the last halves of the 20 th century is World War Il. It is indeed the nusst historically significant wat in is implications. It brought about the tollowing seven consequences to the world:

1. The Sowire Commonist bloc in Eastern Furote, Chinin and Vietnan was established.

2. China gained her independence and the Communist revolution there was successful.

3. Germany lost the pussible hegemony in Central and Western Eutope as the resule of her defeat in the rwo Wortd Wars.

4. Japan lost the leadership she had held in East asia since the end of the 19th cenury.

5. The Bristisl empire dissolved herself despite her victury.

6. Marky cothnics in Asia dnd Africa under the rule of Western powets and Japan succeedeal in beconnug independent statcs.

7. A new world order. Pax-Americana, was exablisherd.

This postwar world order has changed due to the steady economic development of many cu(untries it the past hall century and particularly due to the end of the cold war in recen years. What is patticularly conspicuous in East Asia is the conomic development. Fast Asian nations have concentrated their efforts on conomic development rather than on political struggles for hegemony in the region. "The confrontation of the Communist bloc narions witl the free world nations, however, has nor yet ended in this part of the world. particulariy in tho Korcan peninsula and Indochina. Although the shift in government policics in mainland China, and in Vietnam toward a "Socialist maket economy" and "open door and reform" semss to matk a fundunchtal change in East Asid, the change is still limined to the economic sphete. In the political splete, there has been no sign that the monopolistic controt of the Communist Party has weakened. The situation in the Kotean Penitsulua is particularly urgene. How can wo excrapolate these current trends into the beginning of the next concury? In this paper, I will focus on East Asia, which consists of the Siberian part of Russia, North Kotca, South Korea, Japan, Tawan, Hong Kong (everatier 1997), China and the ten ASEAN countries. 


\section{GEO-ECONOMIC AND GEO-POLITICAL POSITIONS OF INSULAR EAST ASIA AND CONTINENTAL EAST ASIA}

In the discussions of development and security of the region in the 21st connury, nwo problens seem particularly important. The first problem is whether we can maintain the current prosperity of East Asia into the next century. The second problem is the interactions of economic devclopment with the likely situacions in East Asian politics in the medium term future. In order to analyze these problems, this essay contends that the distinction between insular East $\Lambda$ sia and continental East Asia is critically important in the geo-politics and the geo-cconomics of the counuties in the region. The developmental means and national security interests of continental Asian nations-China and Sibcrian Russia - are fundamentally different from those of insular East Asian nations. Here, I define insular East Asian nations as consisting of North and South Korea, Taiwan, Japan and the ten member nations of ASEAN. Japan and the Republic of Kotea are two important countries in insular Easi Asia, which must find an appropriate passage to stcer their courses between the contradictory traction of political security and economic prosperity in the coming 21 st century. Both nations muss pay attention to kcep the balance of power between continental Asia (China and Russia) and the rest of insular East Asia.

Japan and Korea have rarely been considered as a meaningful grouping of nations in the economic or political context. This fact seems strange when compared with ASFAN (Association of Southeast Asian Nations) which was formed as early as 1967. Southeast Asian nations as a group meet regularly for the purpose of exchanging views on mutual cooperation for the security and economic development of thcir own and surrounding nations. The reanon why no regional association in Northeast Asia has yet been established must have been due to the political difficulty in grouping the Soviet Union, the rwo Koreas, Japan, Taiwan, Hong Kong and China in the cold war era. The end of the cold war and the success of the Republic of Kored in establishing diplonatic relations with the USSR (now with Russia) and China suddenly opered up the possibility of establishing closer international ties widh Northeast Asian nations or East Asian nations as well as Southeast Asian nations. There is also a possibility of grouping the Western Pacific nations including Australia, New Zealand and some Pacific nations to achieve more prosperity and better security in this part of the Asia-Pacific.

Neverthelcis, in this paper, I shall fociss on the economic and political relarions among the East Asian nations defined above. Hence, the relations of concern include trade, investment, financial transactions, migration and other economic and political relations between (hina and other East Asian countries. Since China is such a giant economy and nation, the relations of insular East Asian countrics with China require special atcontion. In particular, their relations between insular East Asia with China's coastal provinces would be very different from that with China's inner provinces. These two relations might require separate consideration. However, with regards to the discussion on politi-

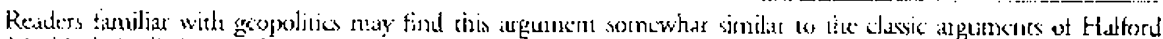

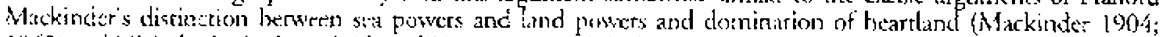

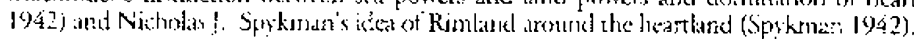


cal security, China must be treated as a single unit. For simitar reasons, on political security issues, Russia and Japan will be treated as separate entities.

\section{BASIC TRENDS IN ECONOMIC DEVELOPMENT AND COOPERAITON IN EAST ASIA}

The political economy of Fast Asia has been changing as a consequence of economic devclopment and the shifting balance of power in the region. Some of the important trends which are likely to persist into the 21 st century are the following.

\section{Sloukr Grouth and the Rise of Domestic Dissatisfaction}

The impressive economic devclopment of both continental and insular East Asian countries offers an important hasis for obtaining the economic and political cooperation of other nations outside of East Asia. It must be recognized, however, that this great performance is not a mitade but the fruit of the blood, sweal, and tears of East Asian nations. 11 one thinks that it is simply an achievement of savings, investment, technological progress and market mechanism, one misses the fundamental aspect of development achieved by human effort and wisdom. The remarkable development of East Asian narions was achieved by a combination of a strong national will for development, hard work, market forces and wise choices in government policies, all in a favorable international environment. Hence, so long as these conditions remain basically unchanged, their development will persist into the 21 st century.

The lapanese expcrience indicates, however, that maintaining rapid growth for a long time is very difficul. Japan's growth rate was $11 \%$ in the $1960 \mathrm{~s}, 6.5 \%$ in the $1970 \mathrm{~s}, 4 \%$ in the 1980 s and $2 \%$ in the 1990 s. In other words, what Simon Kuznets and Kazushi Obkawa called the acceleration and deceleration of the growth rate will also hold in the East Asian cases. This means that the extremely rapid growth rates of East Asian economies will soon slow down, first for Asian Niles (Singapore, Hong Kong, Taiwan and Soun Kored), soon atter for the five ASEAN economies (Malaysia, Thailand, Indoncsia, de Philippines and Victnam), and a litte later for China. Rapid growth makes it easicr to resolve many domestic confliets and sacisfy the wants of general consumets, hut once growth slows down, dissatisfaction may quickly tisc. This may be the case for most East Asian countries in the early 2ist century.

Ir is well-known that East Asian economies have shown the sor-called flying-geese patrem of growth: Japan goes first. Asian NIEs follow, and then the four ASEAN economies follow. This pattern has been disturbed by the rapid growth of coastal provinces in China around four growth cencers: Dalian, Beijing. Shanghai and Guangzhou. As TABlik 1 shows, each of these four groups of provinces have the population equivalent co or larger than most ASEAN momber countries, and is reaching the level of per capita GDP slightly ahove the national average of Indonesia or the Philippines. They are challenging the industries in Southeast Asia by otfering investment opportunities similar to those in 
Southeast Asia. This is likely to accelerate competicion among East Asian economies, and despitc is cffect of expanding the markets, kecn competition may slow down the growth of NIEs and the four ASFAN nations. There is already a clear indication of thesc trends in most East Asian conomies.

\section{Unequal Income Distribution and Regional Disparity}

'The most wortisome case would be a combination of slow growth and income inequality. Income discribution in East Asian countrics is not as bad as that of Latin American countries, but is also not free from possible future problcms. Particularly worrisome is the situation in China, as TABlE 1 shows. These dara seem to imply that the income differentials in China among the social classes as well as among the regions, particularly between coastal provinces and inner provinces, are widening. As Samuel Huntington discusses, ${ }^{2}$ the concept that economic growth may lead to political instability in changing societies may be summarized by the following equations:

Economic Dissatisfaction $=($ Want $) /($ Consumption $)$

Social Dissarisfaction $=($ Economic Dissatisfacrion $) /($ Income Distribution $)$

Political Dissatisfaction = (Sexial Dissatisfaction) $/$ (Social Freedom)

Political Instability $=($ Political Dissatisfaction $) /($ Political Participation $)$

Thete naay be a number of reasons why post-Deng Chincse politics may lead to eventual, if not immediate, instability. Regional disparicy in income is one of the crucial indicators of the futurc uncertainty of Chinese politics.

\section{Increasingly Liberal Trade and Investment and Measures for becoming Gradually More Self-sustaining}

As the World Bank Report publisthed in July 1994 noted, East Asian exports multiplied more than thirty-fold in the recent quarter of a century to about $\$ 850$ billion, increasing the Fast Asian share of the world exports to 21 percent from 7 percent. This implics that imports of industrialized European and American countries from East Asia have risen by 15 to 20 percent per year without receiving any improved access to Asian markets in return. This has caused unsustainable trade surpluses, and rising tension between the U.S. and Japan, China, and other East Asian cruntries. Acceleration of liberalization of their trade regines, and reduction of import tariffs are, therefore, almost a necessity, bearing in mind chat the effecrive rates of protective turiffs in Indoncsia and the Philippines, for cxample, still remain as high as $40 \%$. In fact, a significant number of steps have been taken to deregulate the control of foreign investment in all East Asian countries." This deregulation trend will persist for a while as long as nations are successful in achieving

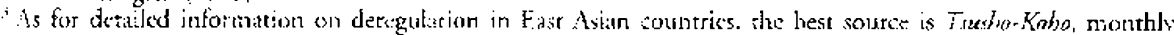






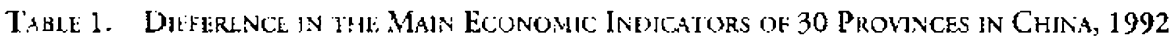

\begin{tabular}{|c|c|c|c|c|c|c|}
\hline Province & $\begin{array}{l}\text { Population } \\
10 \text { thousand }\end{array}$ & $\begin{array}{l}\text { GNP per } \\
\text { capita } \$\end{array}$ & $\begin{array}{c}\text { Forcign } \\
\text { Cases }\end{array}$ & $\begin{array}{l}\text { Industry } \\
1 \text { bil yuan }\end{array}$ & $\begin{array}{l}\text { Agriculture } \\
\text { Ibil yuan }\end{array}$ & \\
\hline 1. Beijing & 1,102 & 1,167 & 2.207 & $1,432.50$ & $1,085.8$ & 84.5 \\
\hline 2. Trarjic" & 920 & 811 & 1,702 & $1,219.81$ & 997.9 & 62.2 \\
\hline 3. Hebei" & 6,275 & $334^{\prime}$ & 1.420 & $1,622.81$ & $1,733.6$ & 419.8 \\
\hline 4. Sh..nxi & 2,979 & 316 & $37 \%$ & 26672 & 744.1 & 131.4 \\
\hline 5. Nei Mongol & 2.207 & 311 & 112 & 88.06 & 361.7 & 180.3 \\
\hline 6. Liaoning ${ }^{2}$ & 4,016 & 586 & 2,417 & 1.94 .19 & $2,337.9$ & 340.8 \\
\hline$\because$ Changethun & 2.532 & 369 & 606 & 9.87 & $76 ? .8$ & 204.3 \\
\hline 8. I freibrojiasng & 3.608 & 430 & 710 & 385.42 & $1,103.1$ & 285.2 \\
\hline 9. Sharighai" & 1.345 & 1,437 & 1.499 & 3.34 & $2,429.3$ & 80.0 \\
\hline 11. Jiangen" & 6,911 & 519 & 7.854 & 1.60 & $4.6,3.6$ & 6.3 .5 \\
\hline 11. Zhejuang" & 4,236 & 523 & 2,338 & $2, \$ 63.03$ & 2.498 .2 & 4048 \\
\hline 12. Anhui & $5,8.34$ & 225 & $70 \mathrm{~L}$ & 353.84 & 995.8 & 390.1 \\
\hline 13. Fujiange & 3.116 & 410 & 3,113 & 6.351 .01 & 915.5 & 3007 \\
\hline 14. Jiangx: & 3.913 & 259 & 206 & .90 & 646.2 & 298.4 \\
\hline 15. Slat & 8.610 & 417 & 4,104 & 9.61 & 53.7 & 840.7 \\
\hline 16. Henan & 61 & -38 & 768 & 51 & 8.6 & 573.7 \\
\hline 1. $\mathrm{He}$ & 80 & 326 & 1.286 & .94 & 3.7 & 435.4 \\
\hline 18. Huthan & 6,267 & 266 & $78:$ & 64 & 06,8 & 仍1.2 \\
\hline 19. Gual & 6,525 & 637 & $97(64)$ & 18 & $3,4: 9,4$ & $73 \overrightarrow{3} .1$ \\
\hline 20. Gitas & 4,380 & 237 & 3.156 & 3.98 & 582.8 & 333.1 \\
\hline 21. Hainan ${ }^{+}$ & 686 & 375 & 1.830 & 14 & 75.7 & $8 ? .2$ \\
\hline 22. Sishuan & 10,998 & 246 & 1,178 & 3.55 & $1,849.8$ & 744.8 \\
\hline 23. Gurisou & 3,3626 & 179 & $? 10$ & 187.38 & 302.3 & 1767 \\
\hline 24. Yuniran & 3,832 & 241 & 204 & 167.97 & $4: 7.1$ & 250.4 \\
\hline 25. Tilnet & 228 & 265 & - & - & 3.9 & 22.5 \\
\hline 26. Gitlysu & 3,405 & 26.3 & 4.44 & 522.90 & 599.5 & 205.3 \\
\hline 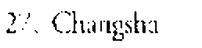 & 2.31 .4 & $23 \%$ & 45 & 27.23 & 367.1 & 122.3 \\
\hline Ix. Qinghai & $4(i)$ & 332 & 13 & 4.1.4 & 68.2 & 273 \\
\hline 29. Ningxia & 487 & 293 & 125 & 43.48 & 89.4 & 28.4 \\
\hline 30. Sinksany & 1,581 & 438 & 24 & 10.45 & 317.2 & $1 \% 2.4$ \\
\hline Total & 117,171 & 372 & 48,125 & $57,874.28$ & $37,065.7$ & $9,084.7$ \\
\hline
\end{tabular}

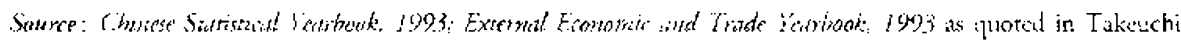
(1) (1)



gradual industrialization in manulacturing sectors. They awe no longer necessarily protecring domestic infant industries, because about half of the exports from the ASEAN countries are the products of multinational corporations. That is why the ASFAN countrites are able eo accelerate the rariff reduction promised in AFTA. Northeast Asian countries should move abcad of them. 
Table 2. CompostTion of EXPORTS trom Major ECONOMIES, 1975 and 1992

\begin{tabular}{|c|c|c|c|c|c|c|c|c|c|c|}
\hline & \multicolumn{2}{|c|}{$\begin{array}{c}\text { Food \& Live } \\
\text { Animals }\end{array}$} & \multicolumn{2}{|c|}{$\begin{array}{l}\text { Crude Mat. } \\
\text { excl. Fuels }\end{array}$} & \multicolumn{2}{|c|}{$\begin{array}{c}\text { Mineral } \\
\text { Fuels. etc. }\end{array}$} & \multicolumn{2}{|c|}{$\begin{array}{l}\text { Animal and } \\
\text { Vegetable Oil }\end{array}$} & \multicolumn{2}{|c|}{ Chemicals } \\
\hline & 1975 & 1992 & 1975 & 1992 & 1975 & 1992 & 1975 & 1992 & 1975 & 1992 \\
\hline Chinid & 16.5 & 2.8 & 9.5 & 3.7 & 23.5 & 5.5 & 0.3 & 0.2 & 6.2 & 5.1 \\
\hline Hong Kong & 1.2 & 1.1 & 0.7 & 0.8 & 0 & 0.9 & 0 & 0 & 0.6 & 3.5 \\
\hline Korea & 11.8 & 2.5 & 2.8 & 1.4 & 2.2 & 2.3 & 0 & 0 & 1.4 & 60 \\
\hline Taiwan & 15.4 & 4.8 & 1.9 & 2.3 & 1.1 & 0 & 0 & 0 & 1.9 & 9.0 \\
\hline Singapore & 7.2 & 7.8 & 13.3 & 2.2 & 250 & 13.1 & 1.9 & 0.7 & 3.7 & 6.5 \\
\hline Malaysia & 6.4 & 3.6 & 35.0 & 10.7 & 10.5 & 12.9 & 16.3 & 6.6 & 0.9 & 2.0 \\
\hline Thailitud & 59.1 & 21.6 & 15.1 & 4.3 & 0.6 & 1.0 & 0.1 & 0 & 0.5 & 2.2 \\
\hline Philippines & 36.1 & 11.7 & 28.4 & 3.4 & 1.6 & 2.0 & 10.2 & 3.3 & 1.0 & 2.3 \\
\hline \multirow[t]{3}{*}{ Indonesia } & 5.2 & 79 & 14.9 & 7.2 & 74.8 & 29.2 & 2.3 & 2.3 & 0.3 & 2.2 \\
\hline & \multicolumn{2}{|c|}{$\begin{array}{c}\text { Basic } \\
\text { Manufactures }\end{array}$} & \multicolumn{3}{|c|}{$\begin{array}{l}\text { Machines } \\
\text { Transport }\end{array}$} & \multicolumn{2}{|c|}{$\begin{array}{l}\text { Miscellaneous } \\
\text { Manufactures }\end{array}$} & \multicolumn{3}{|c|}{$\begin{array}{l}\text { Unclassified } \\
\text { Guods }\end{array}$} \\
\hline & 1975 & 1492 & & 1975 & 1992 & 1975 & 1992 & & 1975 & 1992 \\
\hline Chilla & 22.1 & 18.9 & & 4.6 & 15.5 & $15 \%$ & 40.1 & & 1.1 & 0.4 \\
\hline Hong Kong & 10.3 & 12.6 & & 11.2 & 27.7 & 52.2 & 50.4 & & 23.6 & 1.8 \\
\hline Korea & 29.4 & 25.2 & & 15.0 & 44.9 & 35.8 & 17.3 & & 0.2 & .0 .4 \\
\hline 'Тахуап & 23.7 & 28.3 & & 19.5 & 8.0 & 36.2 & 39.2 & & 0 & 7.7 \\
\hline Singapore & 8.5 & 6.9 & & 22.7 & 55.1 & 6.9 & 9.3 & & 8.4 & 1.4 \\
\hline Malaysia & $1 \% .6$ & 8.5 & & 6.2 & 43.8 & 5.7 & 11.1 & & 1.1 & 0.4 \\
\hline Thailand & 14.3 & 19.1 & & 1.3 & 29.8 & 3.5 & 20.4 & & 4.3 & 1.0 \\
\hline Philippines & 10.4 & 70 & & 0.5 & 18.6 & 4.4 & 15.6 & & 5.9 & 35.7 \\
\hline Indonesia & 1.3 & 26.7 & 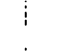 & 0.5 & 5.8 & 0.3 & 19.3 & & 0 & 0.5 \\
\hline
\end{tabular}

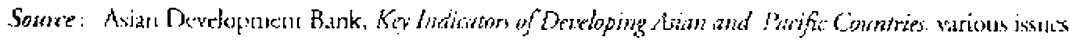

The industries and trade of the ASFAN and Northeast Asian economics have been moving up the ladder of industrialization, as foreign investment has moved into these countries from major industrialized nations. As the per capita GDP increases in each country, changes in industrial composition must be made to keep the competitive edge in increasingly technologically advanced areas. 'This will be difficult for East Asian NIEs. The competition of these Northeast and Southease Asian economies in tecent years can he observed by the changing composition of their major expor items in TABI $\mathrm{x}$ 2. A simple extrapolation of the high growth rates in the past cannot be justified, uniess the tochnological base can be upgraded and human capital support is maintained upward. In this sense, Paul Krugman's (1994) warnings may be taken seriously, although his analysis and extrapolation into the future is basically incorrect.

What is impressive is a steadily incteasing interdependence among Asian NIEs, the ASEAN countries and China. As TABLE 3 shows, their interdependence plays an alrcady 
Tabif 3. Cumulatme Forl:gin Investment bi Colntry in Matr asian Countrids

\begin{tabular}{|c|c|c|c|c|c|c|c|c|}
\hline & & & & & & & & \\
\hline & $\begin{array}{c}\text { Indonesia } \\
196791\end{array}$ & $\begin{array}{c}\text { Malaysia } \\
\text { 1985-91 }\end{array}$ & $\begin{array}{l}\text { Philip. } \\
1980-90\end{array}$ & & $\begin{array}{c}\text { China } \\
1979.90\end{array}$ & $\mid \begin{array}{c}\text { Hong Kong } \\
1985-90\end{array}$ & \begin{tabular}{|c|} 
Taiwan \\
1952.91
\end{tabular} & $\begin{array}{c}\text { Kotea } \\
1982-91\end{array}$ \\
\hline 1. lapan & $11,156.7$ & 4,510 & 314.77 & 3.914 .6 & 3,100 & 1,250 & 4,357 & $2,992.4$ \\
\hline 2. Hong Kung & 4.194 .0 & u & 182.77 & 1.381 .9 & 25,060 & - & $1,562$. & 169.2 \\
\hline 3. Taiwan & $3,3 / 3.1$ & 4,910 & 24.86 & 9 & 2,040 & - &  & 10.2 \\
\hline 4. LSA & 2,1 & $1,250 !$ & 1.191 .79 & $1,6 \% 9.1$ & 4.460 & $1: 214$ & 4,274 & 2.144 .3 \\
\hline 5. Kora & 2.21 & 910 & 9.98 & 57.9 & & - & .. & \\
\hline 6. Necherlands & 2.131 .5 & 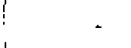 & -1 & 238.3 & $\cdot$ & 148 & $-!$ & 769.5 \\
\hline 7. Germany & $1,803.8$ & - & & 222.6 & 530 & 101 & - & 316.6 \\
\hline 8. 5ingat & 1.5 & 1.440 & 21.85 & 03.5 & 740 & - & - & 68.5 \\
\hline ๖. L.K. & $1,257.0$ & $910 !$ & & 2190 & 600 & 282 & 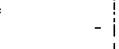 & 245.1 \\
\hline 10. A & & : & & & & & & \\
\hline Ner: 7 & ? & -1 & 3.45 & & 00 & 82 & & \\
\hline (Euro & - & - & 38401 & - & 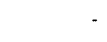 & - & 2,236 & \\
\hline i. L.ux & 530.3 & - & $-!$ & $1.6^{\circ}$ & .. & - & - & \\
\hline . Swill & : & - & - & 225.7 & - & - & - & 286.0 \\
\hline 13. $\mathrm{P}$ & & - & . & - & & . & - & \\
\hline 14. Fian & & - & - : & 136.4 & -5 & - & - & 180.3 \\
\hline 15. Belgium & 7 & . & - & 63.1 & - & . & - & 15.4 \\
\hline 16. $N$ & & - & - & $-!$ & - & - & - & \\
\hline 17. Indi: & & - & & & & - & - & \\
\hline 88. Brume & & 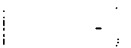 & $-!$ & 0.9 & & & - & \\
\hline 19. Malaysili & 114.5 & - & $10.7 ?^{? !} !$ & 44.3 &  & & - & \\
\hline 20. Indonesia & - & 800 & 0.32 & 13.5 & - & & $-!$ & \\
\hline 21. Cinteda & - & - & . & - & 200 & -1 & - & 23.1 \\
\hline 22. Italy & $\cdot$ &. & - & 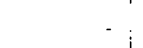 & 210 & & . & 17.6 \\
\hline 23. China & - & - & - & - & 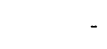 & 422 & - & - \\
\hline 24. Others & 499.1 & 3,450 & - & 316.0 & - & 467 & - & - \\
\hline 25. Mulinat : & $13,421.6$ & - & - & $\therefore$ & - & - & - & \\
\hline Foral & $47,792.2$ & 19,190 & $2,198.58$ & $10,337.6$ & & 3.965 & $-j$ & \\
\hline
\end{tabular}

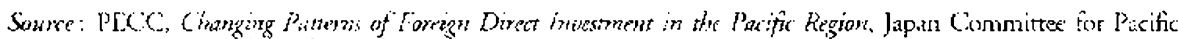

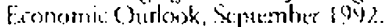

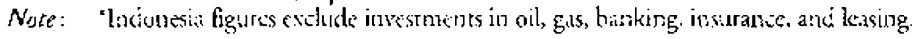

significant role in most developing economies in Southeast Asia and China. East Asian NIEs have changed from simple capital-importing economies to net capital-exporting ones. The closer ties between Northeast Asia and Southeast Asia in trade and investment will become incteasingly cvident. It is still an cxaggeration to argue that trade among East Asian economies is more dominant than that of Fast Asian economies as a whole with the US, and Canada, as others discuss (Watanabe 1997). The cumulative investment figures among East Asian nations are shown in TABlE 3. It is impressive that East Asian NIEs are investing in some countries more than Japan. Intra-regional trade in Asia 
is greater than the corresponding share of Western Europe in Europe's total trade. Per capita levels of trade of the ASEAN counrries are rapidly rising, and the pattern of trade and investment is stcadily approaching the EU type.

\section{Competitive Cooperation in East Asia without Reginnal Integration}

Soon after the Furopean Union was formed, it became fashionable among politicians and economists to promote regional integration as if it were a panacea to move out of economic recession, to resolve political difficuities or to gain political popularity. But it is worth remembering that the miraculous growth of Last Asian economies was achieved basically without the aid of reyional organizations or agrements to support inter-governmental cooperation. The exceptions have been unofficial fora such as PECC, PBEC, EAEC, AFTA, etc., established for the discussion of regional issues by intellectuals, officials and businessmen. Though they are no less important than official organizations for discussions and policy proposals, it is principally market forces that ane responsible for East Asia's miraculous growth. Among official organizations, the ASEAN and APEC are the most conspicuous. They are politically motivated and are inter-governmental. It would be wise not to make $A{ }^{P} E C$ a political organization like the $\mathrm{EU}$ or in intergowemmental agrecment like NAFTA.

The so-called Aying-geese partern will not be appmpriate as a description of the Fast Asian development pattern in the 21 st century. Perhaps, however, the discrepancies berween East Asian countries will still remain wide throughour the 21ss century in terms of the standard of living. This will make in difficult for East Asia to form a regional organization like the EL within a few decades. Beforc East Asian countrics consider such an organization, many economic and political changes will nced to occur in this region.

\section{Urban Growth Centers and Sub-Regional Development}

Onc important feature of East Asian development is the rapid growth concentrated around big cines. Those growth cencers are mostly, but not all capitals such as Tukyo, Osaka, Scoul, Dalian, Bciping, Ticnjing, Shanghai, Taipei, Hong Kong, Guangzhou, Manili, Bangkok, Ho Chi Minh City, Kuala Lumpur, Sinyapore, and Jakarta. Fic.URr. 1 shows the geographic distriburion of such cities with a population of over one million.

TAB1.E 4 shows the change in their tanking among the 30 biggest ciries in the world. Clearly, the population increases of growth conters of the East Asian economies are reflected in this table. This implies that serious problems of urban-living such as pollution, crimes and so on arc likely to become more serious in East Asian growth centers. We have to be prepared for cxtremely grave problems in that respect.

Moteover, these growth centers are currently merging with each other or expanding the economic activitics in coopcration with neighboring areas to attract businesses into their sub-region. Such examples include the Yellow Sea Economic Tone, the Taiwan Fukian 




Sower: Lo and Yeunge

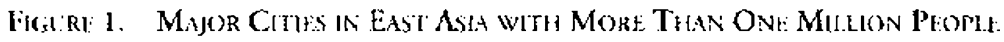

Fconomic Zone, Hong Kong-Shenzhen-Guangzhou Economic Zone, Northeast Thai Zone (with Yunnan-Northcast Myanmar), South Vienam Economic Zone, Suuth Thai- 
TABle 4. ThIRTY BIGGest CITIES IN THE WORLD: 1950-2000

\begin{tabular}{|c|c|c|c|c|c|c|}
\hline No. & 1950 & 1960 & 1970 & 1980 & 1990 & 2000 \\
\hline 1 & $\begin{array}{c}\text { New York } \\
12.3\end{array}$ & $\begin{array}{c}\text { New York } \\
\text { 1.2. }\end{array}$ & $\begin{array}{l}\text { Tukyo } \\
16.5\end{array}$ & $\begin{array}{l}\text { 'l'okyo } \\
21.9\end{array}$ & $\begin{array}{c}\text { Tokyo } \\
25.0\end{array}$ & $\begin{array}{c}\text { Tokyo } \\
27.9\end{array}$ \\
\hline 2 & $\begin{array}{c}\text { London } \\
8 .:\end{array}$ & $\begin{array}{c}\text { Tohyo } \\
\text { t1.0 }\end{array}$ & $\begin{array}{c}\text { New York } \\
16.2 \\
\end{array}$ & $\begin{array}{c}\text { New York } \\
150\end{array}$ & $\begin{array}{c}\text { New York } \\
16.1\end{array}$ & $\begin{array}{c}\text { Bombay } \\
18.1\end{array}$ \\
\hline 3 & $\begin{array}{c}\text { Tokyo } \\
69\end{array}$ & $\begin{array}{l}\text { Landon } \\
9.1\end{array}$ & Shanghai & $\begin{array}{l}\text { Mexico } \mathrm{C} \\
11.9\end{array}$ & $\begin{array}{c}\text { Mexico } \mathrm{C} \\
15.1\end{array}$ & 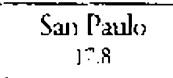 \\
\hline 4 & $\begin{array}{c}\text { Paris } \\
\vdots .4\end{array}$ & $\begin{array}{c}\text { Shanghai } \\
\text { x.8 }\end{array}$ & Osaka & $\begin{array}{c}\text { San Paulo } \\
\text { :21 }\end{array}$ & $\operatorname{San}_{14.8}$ & $\begin{array}{c}\text { Shanghai } \\
172\end{array}$ \\
\hline 5 & $\begin{array}{c}\text { Mesceos } \\
5.4\end{array}$ & $\begin{array}{l}\text { Paris } \\
\because 2\end{array}$ & $\begin{array}{c}\text { Mexico City } \\
91\end{array}$ & Shanghtai & $\begin{array}{l}\text { Shanghai } \\
15.3\end{array}$ & $\begin{array}{c}\text { New York } \\
16 \%\end{array}$ \\
\hline 6 & Shanghai & $\underset{0,8}{\text { Buenos Aires }}$ & $\begin{array}{l}\text { London } \\
8.6\end{array}$ & Osaka & $\begin{array}{c}\text { Bombay } \\
12,2\end{array}$ & $\underset{16.4}{\text { Mexico City }}$ \\
\hline 7 & $\begin{array}{c}\text { Essen } \\
5.3\end{array}$ & Los Angeles & $\begin{array}{c}\text { Paris } \\
\text { H.5 }\end{array}$ & $\begin{array}{c}\text { Buenus Aires } \\
\text { 9., }\end{array}$ & $\begin{array}{c}\text { Los Angeles } \\
11.5\end{array}$ & $\begin{array}{l}\text { Berjing } \\
1+.2\end{array}$ \\
\hline 8 & Buenos Aires & $\begin{array}{c}\text { Essen } \\
6.4\end{array}$ & $\begin{array}{c}\text { Buenos Aires? } \\
\quad 8.4\end{array}$ & $\begin{array}{c}\text { Los Angeles } \\
3,5\end{array}$ & $\begin{array}{c}\text { Beijing } \\
111.9\end{array}$ & $\begin{array}{c}\text { Jakara } \\
14.1\end{array}$ \\
\hline$?$ & $\begin{array}{c}\text { Chicago } \\
4.9\end{array}$ & $\begin{array}{c}\text { Beifing } \\
63,\end{array}$ & Las Angeles & $\begin{array}{c}\text { Calcunta } \\
30 \\
. \quad \ldots . . .\end{array}$ & $\begin{array}{c}\text { Calcurta } \\
: 0.7\end{array}$ & 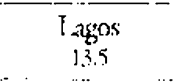 \\
\hline 10 & $\begin{array}{c}\text { Calcurta } \\
44\end{array}$ & $\begin{array}{c}\text { Osaka } \\
6 \ldots ?\end{array}$ & $\begin{array}{c}\text { Beijing } \\
\$ .1\end{array}$ & $\begin{array}{c}\text { Beijing } \\
\text { ?.n }\end{array}$ & $\begin{array}{c}\text { BuenosAire s } \\
10 . i\end{array}$ & $\begin{array}{c}\text { Los Argeles } \\
1,3.1\end{array}$ \\
\hline 11 & Osaka & $\begin{array}{c}\text { Mosow } \\
\text { rit }\end{array}$ & $\begin{array}{c}\text { San Pando } \\
8.1\end{array}$ & P'aris & $\begin{array}{c}\text { Seous } \\
: 0.6\end{array}$ & $\begin{array}{c}\text { Cakurra } \\
: 27\end{array}$ \\
\hline 12 & $\begin{array}{c}\text { Los Angeles } \\
\text { to }\end{array}$ & $\begin{array}{c}\text { Chicago } \\
6 i n\end{array}$ & $\begin{array}{c}\text { Moscow } \\
; 1\end{array}$ & Rio de Janteiro & $\begin{array}{c}\text { Osaka } \\
101.5\end{array}$ & $\begin{array}{c}\text { Tianjin } \\
124 \\
\end{array}$ \\
\hline 13 & $\begin{array}{c}\text { Beijing } \\
39\end{array}$ & $\begin{array}{c}\text { Cakcurta } \\
5.5\end{array}$ & $\begin{array}{c}\text { Rio de Janeird } \\
7 n\end{array}$ & $\begin{array}{c}\text { Seoul } \\
8.5\end{array}$ & Rio de Janeiro & $\begin{array}{c}\text { Seoul } \\
12.3\end{array}$ \\
\hline 14 & $\begin{array}{c}\mathrm{Mikan} \\
36\end{array}$ & Mexico Ciry & Calcutta & $\begin{array}{c}\text { Moscow } \\
8.1\end{array}$ & $\begin{array}{c}\text { Paris } \\
9.3\end{array}$ & $\begin{array}{c}\text { Karachi } \\
l \cdots i\end{array}$ \\
\hline 15 & $\begin{array}{c}\text { Berlin } \\
3.3\end{array}$ & $\begin{array}{c}\text { Rio de Janeiro! } \\
49\end{array}$ & $\begin{array}{c}\text { Chicago } \\
6 .\end{array}$ & $\begin{array}{c}\text { Bombay } \\
\text { s.1 }\end{array}$ & $\begin{array}{c}\text { Tianjin } \\
9.3\end{array}$ & $\begin{array}{l}\text { Delhi } \\
\text { l? ? }\end{array}$ \\
\hline 16 & $\begin{array}{c}\text { Mexico C } \\
3.1 \\
\end{array}$ & $\begin{array}{c}\text { San Pave } \\
4 ?\end{array}$ & $\begin{array}{c}\text { Essen } \\
6.6\end{array}$ & London & $\begin{array}{c}\text { Jakarta } \\
23\end{array}$ & $\begin{array}{c}\text { Buenos Aires } \\
\text { I1. }\end{array}$ \\
\hline 17 & $\begin{array}{l}\text { Philadelphia } \\
\left.2 .{ }^{\prime}\right)\end{array}$ & $\underset{4 i 5}{M}$ & $\begin{array}{c}\text { Bombay } \\
; x\end{array}$ & $\begin{array}{c}\text { Tianjin } \\
\therefore i\end{array}$ & $\begin{array}{c}\text { Moscow } \\
9.0\end{array}$ & $\begin{array}{c}\text { Manila } \\
\text { :c:8 }\end{array}$ \\
\hline 18 & St. Petcrsburg & $\begin{array}{l}\text { Bombay } \\
4.1\end{array}$ & $\begin{array}{c}\text { Milan } \\
5.5\end{array}$ & $\begin{array}{c}\text { Cairo } \\
6.9\end{array}$ & Cairo & $\begin{array}{l}\text { Cuiro } \\
107\end{array}$ \\
\hline 19 & $\begin{array}{c}\text { Bombay } \\
2.9\end{array}$ & $\begin{array}{c}\text { Caro } \\
5 \%\end{array}$ & $\begin{array}{c}\text { Cairo } \\
4.3\end{array}$ & $\begin{array}{c}\text { Chicago } \\
1.8\end{array}$ & $\begin{array}{c}\text { Delhi } \\
8 ?\end{array}$ & $\begin{array}{l}\text { Osaka } \\
111.6\end{array}$ \\
\hline 20 & $\begin{array}{c}\text { Rio do Janeiro } \\
2 \%\end{array}$ & $\begin{array}{c}\text { Philadelphia } \\
3.6\end{array}$ & Scoul & $\begin{array}{c}\text { Essert } \\
6.3\end{array}$ & $\begin{array}{c}\text { Manila } \\
\text { s.0 }\end{array}$ & $\begin{array}{c}\text { Rio de Janciro } \\
\text { 10? }\end{array}$ \\
\hline 21 & $\begin{array}{c}\text { Detroit } \\
2.8\end{array}$ & $\begin{array}{c}\text { Tianjin } \\
3.6\end{array}$ & $\begin{array}{c}\text { Tianjiri } \\
52 \\
\end{array}$ & $\begin{array}{c}32 \mathrm{kiarta} \\
60\end{array}$ & $\begin{array}{c}\text { Karachi } \\
8 . t\end{array}$ & $\begin{array}{c}\text { Dahka } \\
\text { In: }\end{array}$ \\
\hline 22 & $\begin{array}{c}\text { Naples } \\
28\end{array}$ & $\begin{array}{c}\text { Detroir } \\
\quad \quad .5\end{array}$ & $\begin{array}{c}\text { Philiedctphiza } \\
4.0\end{array}$ & $\begin{array}{c}\text { Manila } \\
6: ?\end{array}$ & \begin{tabular}{c} 
Lagen \\
$7 ?$ \\
\hdashline$\ldots$
\end{tabular} & Paris \\
\hline 23 & $\begin{array}{c}\text { Manchesrer } \\
2 . j\end{array}$ & St. Pelersberg & St. Petersbeng! & $\begin{array}{c}\text { Delhi } \\
5.6\end{array}$ & $\begin{array}{c}\text { london } \\
: 3\end{array}$ & $\begin{array}{c}\text { Iscanbul } \\
9.3\end{array}$ \\
\hline
\end{tabular}




\begin{tabular}{|c|c|c|c|c|c|c|}
\hline No. & 1950 & 1960 & 1970 & 1980 & 1990 & 2000 \\
\hline 24 & $\begin{array}{c}\text { San Paulo } \\
\ldots 1\end{array}$ & $\begin{array}{c}\text { Berlin } \\
33\end{array}$ & Detroit & $\begin{array}{c}\text { Milan } \\
53\end{array}$ & Chicago & $\begin{array}{c}\text { Moscow } \\
43\end{array}$ \\
\hline 25 & $\begin{array}{c}\text { Cairo } \\
2.4\end{array}$ & $\begin{array}{c}\text { Naples } \\
3.2\end{array}$ & $\underset{3 . j}{J}$ & Teheral & $\begin{array}{c}\text { Istanbul } \\
6.5\end{array}$ & $\operatorname{Lima}_{3.4}$ \\
\hline 26 & Tianjin & $\begin{array}{c}\text { Shenyang } \\
2.9\end{array}$ & $\underset{3.6}{\text { Naples }}$ & $\underset{i, y}{\text { Karachi }}$ & $\operatorname{Lim}_{65}$ & $\begin{array}{c}\text { Telueran } \\
73\end{array}$ \\
\hline 27 & Birmingha & Frankfiut & Mantila & Bangkok & $\begin{array}{c}\text { Essen } \\
6.4\end{array}$ & $\begin{array}{c}\text { London } \\
\therefore 3\end{array}$ \\
\hline 28 & Frankturt & $\begin{array}{c}\text { Jakana } \\
27\end{array}$ & $\begin{array}{c}\text { Delhi } \\
3.5\end{array}$ & St. Pecersberg & $\begin{array}{c}\text { Teheran } \\
64\end{array}$ & Bangkok \\
\hline 29 & $\begin{array}{c}\text { Bostom } \\
2 ?\end{array}$ & Hong Kong & Shenyang & Hong Kong & $\begin{array}{c}\text { Bangkok } \\
5.9\end{array}$ & $\begin{array}{c}\text { Chicago } \\
\quad 13\end{array}$ \\
\hline 30 & $\begin{array}{c}\text { Hamburg } \\
22\end{array}$ & $\begin{array}{c}\text { Manchester } \\
2.6\end{array}$ & $\begin{array}{c}\text { I Iong Kong } \\
7.5\end{array}$ & $\operatorname{lima}_{4.4}$ & $\begin{array}{c}\text { Dinka } \\
5.9\end{array}$ & $\begin{array}{c}\text { Hyderabad } \\
5 ?\end{array}$ \\
\hline
\end{tabular}

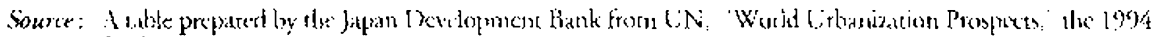
Revisien.

Penang Zone, Growth 'Triangle (Johor Baru-Singaporc-Bantam), Jakarta-Surabaya Megalopolis, Manado-Mindanau 7onc and so on. Most of them are the natural extension of growth centers through markets, though some are the result of deliberate efforts by relevant governments or international organizations. In the insular parts of East Asia it seems importan to enlarge the market size by investing in these sub-regional development projects, thereby realizing the economy of scalc in manufacturing while mitigating overeoncentration in old growth centers. In this comext, the role of multinational corporations is often very important and their contribution in promoting intra-industrial trade should be positively evaluated. The shifis in their relative importance reflect the grouvth pattern in each sub-region in East Asic. These trends will likely continue well into the 21 st century and play an important role in forming the transnarional development partern of East Asian economies.

\section{The Need for Regional Balance In Foreign Direct Investment}

Among all these crends, the most important determinant for relative success in the rivalry between insular Asia and China is the direction of foreign direct investment. Investment in China must. therefore, be carefully evaluated from this perspective. The Taiwanese government permitted free investment in China via I long Kong several years ago, but it is recently under reconsideration, because it may be making the adversary two strong, and working against the interests of Taiwanese businesses. Moreover, it may involve risk in economic acrivities as well as have negative political implications. The same consideration must be taken by any other East Asian country. Conceming this issue, there was an interesting survey conducted by Japan Industrial Bank (Nithon Kogyo Ginko) in 1993. It asked about the 
invesunent intention of Japauese leading corporations for the coming five years. A summary of the findings can $b x$ found in TABIE 5 . It presents several interesting findings:

a) ASEAN was regarded slightly more attractive by Japanese investors as late as 1993, when Japanese investment in China was booming.

b) The domestic markets of ASEAN and China have become significantily large enough, so that Japanese irvestment has beetn planned not only for exports but also fur domestic markets. Nevertheless, this has not reduced che attractiveness of investment opportunities.

c) The replies to the questionnaire shedules secm to show that Japanese invesunent in China expanded very significantly in 1992 and 1993 but slowed down in 1994. This slow pace secmed to continue for some time. Recently, Japanese businesses have become more cautious than in the early 1990s in investing in Chira. Those industries and areas marked "00" are still attracting Japanese investment but less so now chan in 1992 and 1993. They seem to be finding investment in some Southeast Asian countries safer and more preferable. Perhaps similas observacions can be made abour investments from Korea and Tiawan as well. If so, this is as they shoukd be. As the author belitwes, the balance in economic development pace between Chima and the rest of East Asia is highly desirable not necessarily in the per capita level but is the rotal $\mathrm{CNP}^{2}$. Needless ro say, the popularion size is a crucial factor.

\section{THE CHINA PROBLEM IN EAST ASIA}

The most serious problen facing East Asia is, as I have pointed out above, the balance of power between insular Asia and continental Asia, particularly China. We all know that the most remarkable economic expansion has taken place recently in China. Its sheer sizc has many political as well as economic implications. In the fourteenth Party Congress in 1992, Chinese leaders chose to take bold steps toward a socialist market economy. In a sense, it was following the Singaporean model - i.e., a market economy with very strong authoritarian governmental guidance and influential state cnterprises, with little freedom of press, assembly and association. It was no arcidest that the former prime minister of Singaporc served as an economic adviset to the Chinese ocntral govemment for many years.

As we have observed, however, in almost all the other East Asian nations, the achievement in economic growth leads to the democtatization of the political system in the country step by step, although the path may differ from one nation to another, and the speed may be very slow. There are several reasons why we should carefully observe China." The teasons are:

a) China has nuckar military capability with full-scale reckets, so that if its economy became as powerfil as that of the former Soviet Union, it could be a threat to ncighboring nations, as well as the Unired States.

b) It absorbed Hong Kong in 1997. Thus it increased its leverage greatly in terms of influenc-

\footnotetext{
Sox Muricy od (1993). This book is bxing revised for now cdition.
} 
Table 5. aSEAN yersl:s Chinese Markets to Japanese Major Inibustriat. Investors

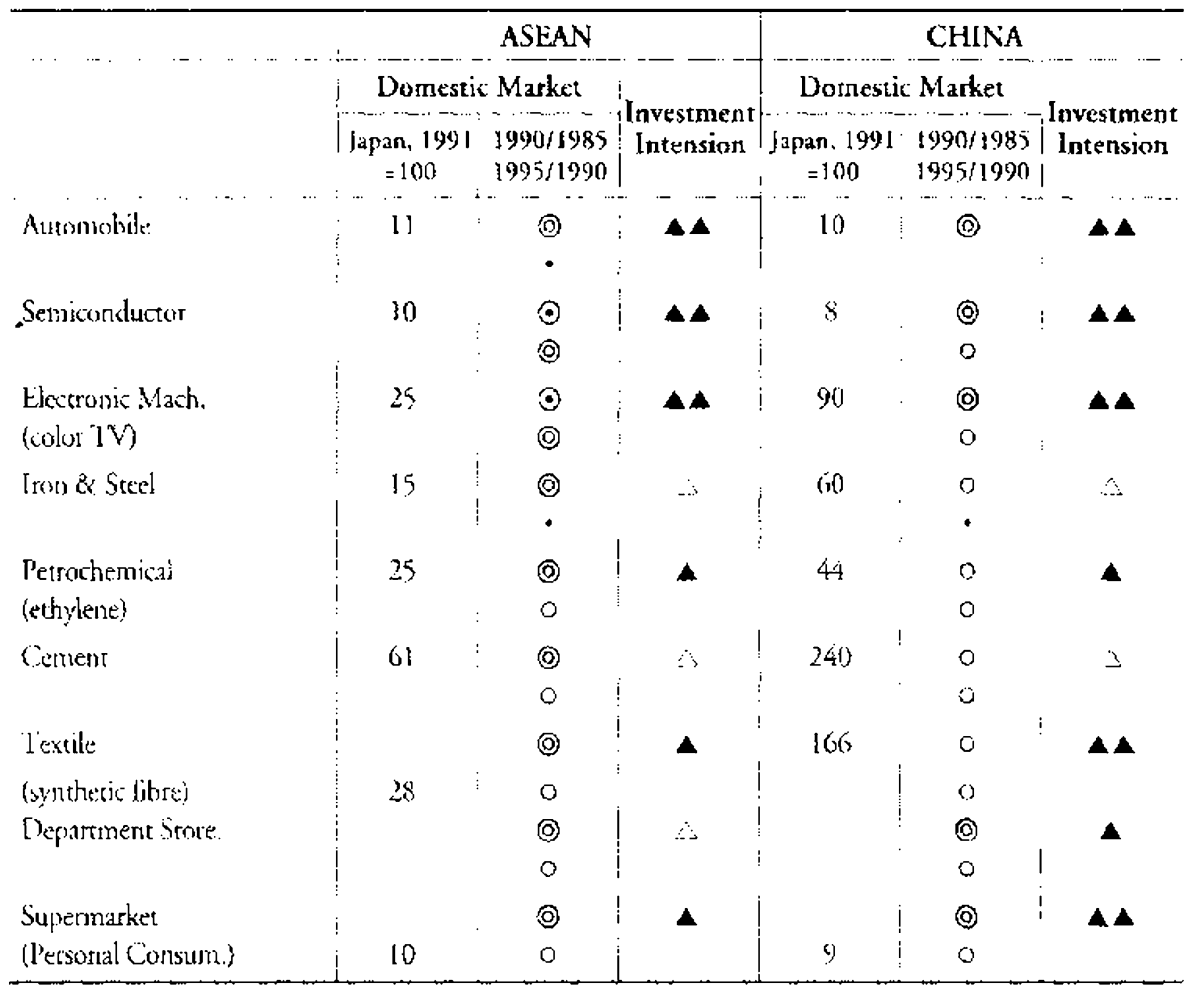

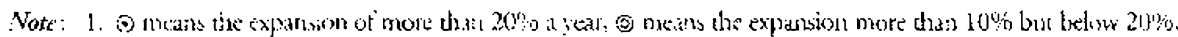

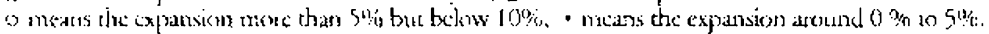


expiust.

ing trading panners and overseas Chinese communities.

c) It is closcly linked witl the significant economic power of overseas Chinese in Southeast Asia. Greater China nuay soon become as influential as Japan, South Korea, Asian NIEs waken together. TaBiF 6 provided by the World Bank (1993) demonstrates the amazing porential of the Greater Chinese Area.

d) It is moving towards closer relations with Russia. In fact, China is now second only to Germany in tracte telations with Russia.

e) Nevertheless. the majonity of Japanese politicians and businessmets are optimistic in presuming that rising per capta inconce will nocessarily lead to denocratization of the political system, even in Chind. 3 nd will result in improved relations with neighboring countries. On the other hand, the linited States seems to be pessimistic hecause of two possibilities. One is that China nay hecome a dictatorial country with little desire to protect the rights of its cirizen:i and will become an adversay to L.S. interests in Asia. The second is the exceedingly 
Tabil: 6. GDP Comparisons for four Economies: Makket Price añd Standard International. Price. Estimates

(unit: L'S. \$ triljon)

\begin{tabular}{l|c|c|c|cc}
\hline & \multicolumn{2}{|c|}{ At Market P'rices } & \multicolumn{2}{c}{$\begin{array}{c}\text { At Standard } \\
\text { International Prices }\end{array}$} & Per capita \\
\cline { 2 - 6 } & 1991 & 2002 & $1990^{2}$ & 2002 & $(\text { US } \$)^{\mathrm{h}}$ \\
\hline Chinese Fconomic Area & 0.6 & 2.5 & 2.5 & 9.8 & 7,300 \\
United Stares & 5.5 & 9.9 & 5.4 & 9.7 & 36,000 \\
Japan & 3.4 & 7.0 & 2.1 & 4.9 & 37,900 \\
Germany & 1.7 & 3.4 & 1.3 & 3.1 & 39.100 \\
\hline
\end{tabular}

Source: Worid Bank, Buze line Forentat tichuary 1993.

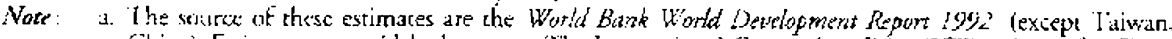

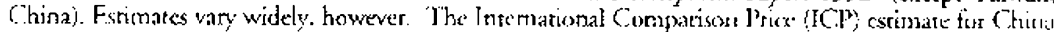
in 1990 nay be conservative. Fur initants, the Summers and Heston ICP estimate for 1985 was

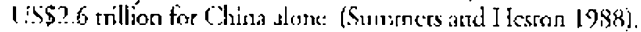

b. Pr's carica figutes are sexpressed in thousands of L.S. dollars. In making the ICI' projecrisons, it is

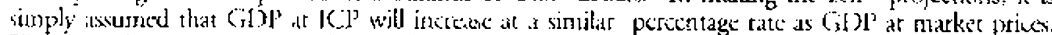
This genwe) rate is an upper bound for the (hinese Economic Area (C.EA) trecause Interinational


as relacive incom: per sapita rises ípeflecting the highter relarive price of sesores in high-income ecot(u)

close relations between Japar and China. Economic cooperation in East Asia nuust keep these concerns of the United States in mind."

The great uncertainty about the future of China is duc to the difficulty in overconing scveral key factors: the scccession problem, regional income ineyuality, domcstic migration into urban areas, systemic corruption with limited moraliry in public administration, strong trends for decentralization, uncontrollability of the military, and non-existence of governmental offices like the Japanese MIII to guide the state, collective, and private enterprises. The most imminent problem is whether post-Deng China will return to a dictatorial regime and suppress corruption in order to maintain national wnification or if it will succeod in controling the contral government party and the army by oligarchy. If Chinese kaders fail to control the central government, Japan may find it difficult to be friendly to both the United States and China. Japan will then face a choice either to remain an ally to the U.S., moving away frum friendly relations with China (this is the majority view in Japan), or to move closer to China, a kind of Asianism which is a minority view.

In the former, Japan-China relations will be in tension. As Professor Huncington of Harvard University points out, the weakening U.S. may welcome the wnflict between Clina and Japan that will werken both. On the other hand, in the latter case, there is a danger for China and Japan to become mutually compromising and very fricndly to each other against the national interests of the U.S. in Asia. In that case, the role to be played by Korea, Vietnam and ASEAN as a whole will be very crucial in balancing the power of both powers, as Poland and Belgium did after the Vienna Conference in Europe. The

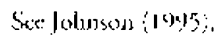


majority of intellectuals in Japan believe that it would be very unwise to chnose the lattet course. This may be the pessimist s view in the U.S. as well. Many diplonats and politial sciemises in the U.S. and lapan repeatedly emptasize that the key to the stability in Eass Asia is the trust of Asian nations in the security arrangements between the U.S. and Japan.

If, however, China succeeds in keeping its rapid pace of development and becomes too confident, then it may scek its own hegemonic course, particularly toward smaller neighbors. In order ro avoid such a sicuation, it is highly desirable to have a good understanding among Asian nations on the relations between cononic devclopment, political stability. and security.

\section{RESOLVING REGIONAL, SECLRITY ISSUES}

There are several fora alteady in Ease Asia to discuss the regional security problems. The most aurhoritative one is the ASEAN Regional forum cstablished as a part of the regular Extended Foreigus Ministers Conterence of ASFAN, whose first taceting was held in Bangkok in 1994. The second is the CSCAP (the Council for Sccurity and Cooperation in Asia-Pacitic) proposed in Seoul in 1992 and confirmed in 1 ombok in 1993, which is similar to dhe (SCE. in Furops, tut is a nuore informal gathering of selected national research institutes of the ASEAN member countries- Korta, Japan, the L.S. Australia and New zealand. These nations could be the oore group with which ro discuss matket ecomomics and security problems in addition wo bilateral relations of the L'S. with each momber nation. The third is the whual conference of che Asia-Pacific Reundable sponsored by the Institute of Serategic and International Studics in Malaysia in conperation with the same types of insrimes in almost all Asia-Pacific countries. The conference is organized on the basis of individual participanes so that a wide range of nations including China (PRC.. Russia, North Korea. India, and Tawan. which are outside of the scope of CSCAL, are represented.

It is importan for Notheast and Southeast Asian mations to build up confidence in each onlue through sincere and frank exchanges of opinions on security and development issuch facing sach natron. They must recognize the benefit of pace and mutual cooperacion and find atn optimal way to resolve conflicts among themselves in both economic and political matters. Wo musr explore varjous opinions useful for confidence-building and muctal trust. It is important not to taks advantage of the weakncsses of orher nations. buc to help then overcome them, while also learning from their stengths to tind Lle optimal means of achicving balanced development among all nations in the region.

There seenis w be an urgent need for this type of cooperation in Fast Asia, in light of the widely-recognized rising risks in Asian countrics. The credit rating as evaluated by Furomone Joumal it: TABls: 7 demonstrates this rising risk. This rating does not warrant any optimism for Northeast Asian countrics. Indeed, one of the most serious tensions in the world may now be in the Korian peninsula and the Taiwanese Straits. To resolve regiond contlicts throngh the efforts of Asian nations requires much friendlier contistlat- 
Iable 7. Changes in Counjery RISks or Asian Nations

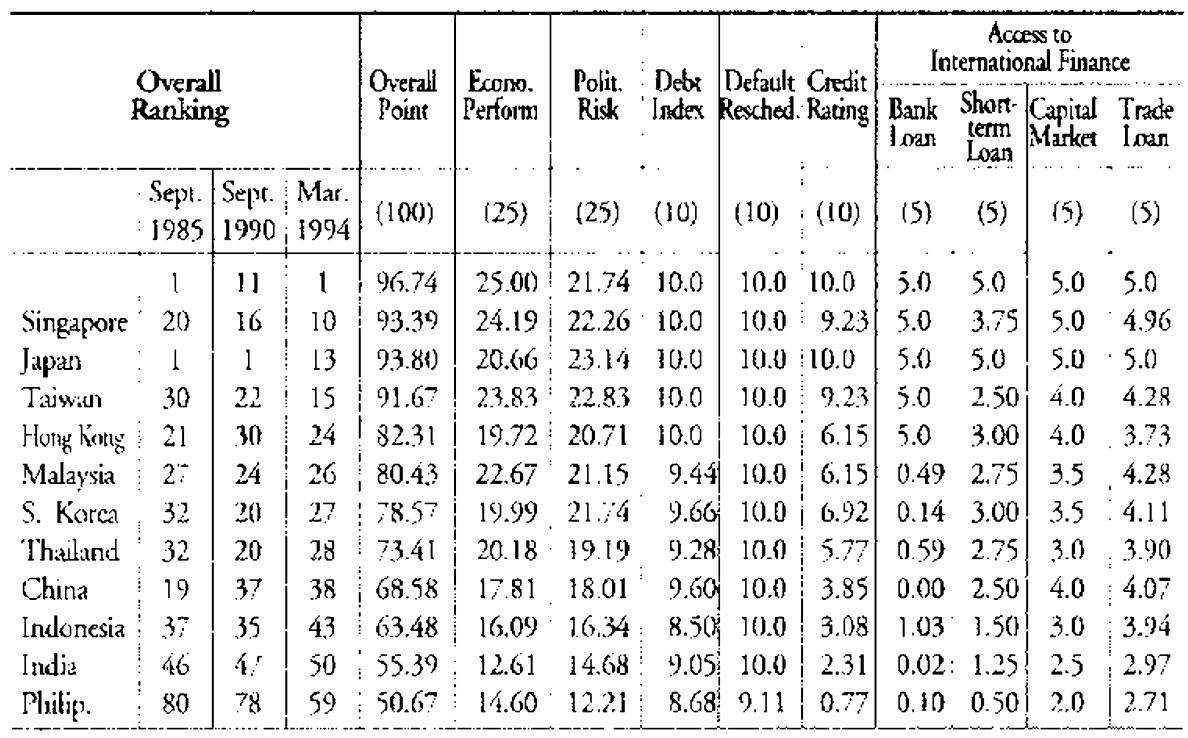

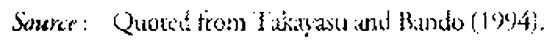

tion and exchanges of opinions on security problems in addition to economic cooperation.

\section{JAPANESE EFFOR'TS FOR HER OWN SECURITY AND REGIONAL POLITICAL STABILITY}

Japanesc efforts seem to be directed in three areas. The first is to maintain trust in bilateral alliance; primarily with the United States (Mutual Security Agrement), and co continwe to improve bilateral political relations with Russia and China. For instance, Japan has continued the following consultations and dialogues: Japan-Russia Policy Planning Consultation (June, 1992; February, 1994), Japan-Russia Defense Research Exchange (February, 1993; March, 1993), Japan-Russia Maritime Accidents Prevention Agreement (signed in 1993), Japan-China Security Dialogue (the first mocring betwecn defense authoricies of botb countries in March 1994). It must be added that similar efforts have becn made with other Asian councries through the exchange of visits hetween Japanese and Asian (Korcan and Southeast Asian) defense ministers. These efforts will continue, but should not be considered, as the Newspaper Asahi reported, as a new direction of Japanese efforts toward the Asianism mentioned above.

The second is to improve mutual trust among insular Asian nations by what is popularly called "Confidence-Building Steps." This is parricularly important vis-à-vis Korea 
and China. Japan has many problens in erasing the wartime guilt or misbehaviors of half a century ago. By making fresh efforts to extend economic and other types of cooperation, Japan is hoping to build up new trust with neighboring Asian nations. However. it is very difficult particularly with Korea and China. Building up trust seems to be proving soncwhat less worrisone with Southeast Asian nations. This may be a reflection of the four-fold nature of World War Il in Asia: war against China; war against the U.S. and Western countries: wat against the USSR; and war against Japanese colonialism. It will take nore rime to remedy all the grievances of the sufferets in other Asian countries. Japan must continue to make efforts to console the minds of those peaple by offering whatever help she can.

The third is to achieve arms control or arms reduction by mutual dialogue eo reduce tensions in East Asia. Positive participation in the dialogues at the ASEAN Regional Forum or similar conferences nucntioned above seems to demonstrate Japan's interest in maintaning the low level of military build-up in the Asia-Pacific. As economic development becomes suxcessful, on the contrary. Fast Astian countries are also spending more on military expansion. The army is no longer just for domestic law and order, but ruly for national defense in many countries. Hence, it is all the more important for Japan and other List Asian nations to maintain the constant dialogue and to build up mutual confidence. All East Asian councries including China must make military activities more transparena, so that cach will reduce mititary build-up and release more resources for cconomic development. This path will prove to be the golden road to increase the prestige of Fast Asian nations and to produce more culturally impressive fruit in the next cenary.

\section{REFERENCES}

Asian Devidopment Bank. Koy Inticatom of Developing Asian and Pacific Countriei various issues. Huntingron. Samuel P. 1968. Political Order in Changing Socketies. New Haven: Yade University Press.

Idimurd, S. 1994a. "Regional Integration Issucs in Asia." AFIA after NAFTA, Acadenic Studies Seris: Join Kurca-L!S. Academic Symposium. Vol.4.

[chimura, S. 1994b. "Rerent 'l tends of the New World Order and Regional Integrarion and Japun." Polisics and Economics in a Drastically Chunging World, I'roposal 21, Vol. 1. Sagano Shoin Kyots.

Johnion. Chalmers. 1995. "Worries About Japanese Mppeasement on Chisa." Nikkei Shinbun. November 25.

Kngman, Paul. 1994. "The Myth of Asia's Miracle." Foreign Affary. 73(6), 62-78.

Kinoshita Foshio. 1997. "Hardly Autonomous Cycles." Look Japan, March.

Is, Fu Chen, and Yuc-Man Yaung. "Fmerging Wotd Cities in Pacific-Asia."


44.

Mackinder, Halford J. 1942. Demornatic Ldeals and Realify. New York: H. Holt \& Co.

Morley, Jatnes W. ed. 1993. Driven by Crow th: Political Change in the Assa-Pacific Region. New York: M.E.Sharp.

Noman, E. Herbert 1940. Japan's Emergence As A Modern State-Political and Economic 
Problems of the Meiji Period. New York.

PFC.C. 1992. Changing Patterns of Foreign Direct Investment in the Pacific Region. Japan Committee for Pacific Économic Outlook. Septenber.

Spykmat, Niciolas J. 1942. America's Strattgies in World Politics. New York Harcourt Brace \&i Co.

Summers, Robert and Alan Heston. 1988. "A New Set of International Comparisons of Real Product and Prices: Estimates for 130 Countries." Review of Income and Wealth, 34(1), 1-25.

Takayasu, Kenichi, and Bando, Shunsuke. 1994. "International Financial Business in Asia: Focusing on Japanese Financial Institutions." RIM, Sakura Institute of Rescarch. No. 26

Takeuchi, Junko. 1994. "China's Growing Industrialization and Japanese Company Investment." RIM, Sakura Institute of Research, No. 27.

UN. 1994. "World Urbanization Prospects." "1he 1994 Revision.

Watanabe, Toshio. 1997. "Growing Alone:" Loak Japan, January.

World Bank. 1993. Base-line Foretast. February.

World Bank. 1992. World Development Repart 1992.

Yasukuni, Kyoko. 1994. "Current Situation and Prospect for Foreign Investment in ASEAN Countries," RIM. Sakura Instirute of Research No.27. 